\title{
Histopathologic profile of mastectomy specimens of operable breast cancer cases
}

Endang Sri Roostini ${ }^{*}$, Goi Sakamoto ${ }^{\dagger}$, Susumu Watanabe ${ }^{\star}$, Muchlis Ramli^, Joedo Prihartono§, Santoso Cornain*, Yoshiyuki Ohno ${ }^{\star}$, Esti Soetrisno*, Gunawan Tjahjadi*, Idral Darwis*, Didid Tjindarbumi*, Setyawati Budiningsih ${ }^{\S}$, Nakako Kubo\#.

\begin{abstract}
Abstrak
Informasi yang adekuat mengenai profil histopatologik dari sediaan mastektomi memberikan ramalan yang lebih baik tentang prognosis tiap penderita kanker payudara. Sejauh ini, belum pernah dilaporkan data dari kasus-kasus di Indonesia, yang antara lain disebabkan karena pada umumnya kasus-kasus yang datang sudah pada stadium lanjut yang inoperabel. Pada makalah ini akan dilaporkan profil histopatologik dari sediaan mastektomi kasus kanker payudara yang operabel yang tercakup dalam penelitian bersama Indonesia-Jepang, tentang Etiologi dan Klinikopatologi pada Kanker Payudara. Dari tiap kasus, diperiksa masing-masing 4-6 sediaan HE untuk dinilai jenis histopatologinya, sebukan limfosit, invasi pembuluh darah dan limfe, invasi jaringan lemak, otot dan kulit serta penyebaran ke kelenjar getah bening. Juga dikumpulkan data-data ketahanan hidup 5 tahun. Sebanyak 70 dari 107 kasus yang operabel dapat dinilai secara lengkap sediaannya dan pada 20 di antaranya dianalisa untuk ketahanan hidup 5 tahun. Mayoritas kasus adalah jenis duktal invasif $(79,9 \%), 2,8 \%$ duktal in situ dan sisanya adalah tipe khusus. Jenis skirus merupakan yang terbanyak di antara jenis duktal invasif (43\%). Limapuluh kasus menunjukkan sebukan limfosit, namun separuhnya adalah derajat ringan. Invasi vaskuler hanya ditemukan pada 4 kasus, invasi pempuluh limfe pada 16 kasus. Invasi lemak pada 36 kasus, otot pada 3 kasus dan kulit pada 1 kasus. Di antara 48 kasus dengan sediaan kelenjar getah bening, 28 kasus menunjukkan metastasis. Usia penderita dan sebukan limfosit merupakan gambaran yang cukup menonjol dalam kaitannya dengan ketahanan hidup 5 tahun. Terlihat kecenderungan penurunan usia dari kelompok hidup tanpa penyakit, kelompok hidup dengan penyakit dan yang meninggal. Pada kelompok yang hidup tanpa penyakit sebukan limfosit derajat sedang sampai keras terdapat pada sebagian besar kasus, sedangkan pada kelompok hidup dengan penyakit, sebukan limfosit umumnya berderajat ringan. Pada satu kasus yang meninggal tidak ditemukan sebukan limfosit. Disarankan untuk melakukan studi serupa lebih lanjut dengan menggunakan teknik-teknik mutakhir agar didapatkan informasi yang lebih akurat mengenai profil histopatologik yang adekuat.
\end{abstract}

\begin{abstract}
Adequate description of histopathologic profile of mastectomy specimens offers a better prognostic prediction of individual breast cancer patient. Such a data hasn't been reported so far from Indonesian breast cancer cases, due to the fact that the majority of admitted cases were already in unoperable late stage. In this report, we present the extensive histopathologic profile of mastectomy specimen from cancer cases included in Indonesia - Japan Joint Study on Etiology and Clinicopathology of Breast Cancer. Four to $6 H \& E$ slides were reviewed from each cases; all data about histopathological type, lymphocytic infiltration, blood and lymph vessels invasion, fat, muscle and skin invasion and lymph node involvement were recorded. Five years survival data were collected. Only 70 out of 107 operable cases were available for a complete histopathological review and 20 cases were evaluated for their 5 years survival data. Most of the patients were of ductal invasive type (79.9\%); $2.8 \%$ ductal in situ and the rest were of the special types. Scirrhous subtype predominated the ductal invasive type (43.3\%). Fifty cases showed lymphocytic infiltration. Vascular invasion were found only in 4 cases, lymph vessel invasion in 16 cases. More than half cases showed fat invasion (36 cases), muscle invasion in 3 cases and skin invasion in 1 case. Among 48 cases with dissected lymph node, 28 showed metastasis. Age of patients and lymphocytic infiltration were significant encountered in the evaluation of survival data. There was a tendency for a decreasing age among group alive without disease, alive with disease and deceased. Almost all of cases who were alive without disease showed lymphocytic infiltration which were mostly moderate to severe; while 6 cases who were alive with disease mostly showed mild infiltration. One case who was deceased has no lymphocytic infiltration. It is recommended to study further with the help of ancillary techniques to get more accurate information about the histopathologic profile.
\end{abstract}

Keywords : Histopathologic, breast cancer, mastectomy specimen.

\footnotetext{
* Department of Pathology, Faculty of Medicine, University of Indonesia, Jakarta 10430, Indonesia

† Department of Pathology, Cancer Institute Hospital, Tokyo 170, Japan

- Department of Surgery, Faculty of Medicine, University of Indonesia, Jakarta 10430, Indonesia

$\$$ Department of Community Medicine, Faculty of Medicine, University of Indonesia, Jakarta 10320, Indonesia

- Department of Preventive Medicine, Nagoya University School of Medicine, Nagoya 466, Japan
} 


\section{INTRODUCTION}

Breast cancer is the second most frequent malignancy among women in Indonesia. ${ }^{1}$ Previous report on our study revealed that most breast cancer patients, namely $87 \%$, came in their late stage (2). So, only few of them were subjected to surgical treatment and no information about extensive histopathologic profile was reported so far in our country.

There are many factors known to influence the prognosis or clinical outcome of breast cancer patient. An extensive histopathologic profile of mastectomy specimen provides more accurate information about the prognosis of the individual breast cancer case than the small biopsy specimens.

In this study, various histopathological finding on mastectomy specimen will be reported and correlated to the clinical outcome whenever possible.

\section{MATERIALS AND METHODS}

The samples of this study were part of the total samples of 300 cases including in the Indonesia-Japan Joint Research Project on Breast Cancer: an epidemiological study. Only 107 out of 300 cases were operable.

The mastectomy specimens, consisting 4 to 6 routine $\mathrm{H} \& \mathrm{E}$ slides section taken from the tumor and surrounding tissue, were reviewed histopathologically for their histopathologically types, lymphocitic infiltration, blood and lymph vessels invasion, fat and muscle tissue invasion. Lymph nodes section were also reviewed and counted for the presence of metastatic tumor cell. Clinical data about their survival were recorded.

Histological typing was done according to the Japanese classification for breast cancer (3); lymphocitic infiltration was graded according the severity as mild, moderate and severe. Tumor emboli in the blood and lymph vessels were search and also the destruction of the vessel's wall by the tumor cells.

Fat infiltration was recorded either within interlobular fat or submammary fat tissue. Same observation was done for muscle tissue.

\section{RESULTS}

Seventy cases were available for a complete review. The histological type is presented in Table 1. Lymphocyte infiltration were present in 50 cases $(71.4 \%)$.
Most of them were of mild infiltration (50\%). Most of the scirrhous types were not or only mildly infiltrated by lymphocyte compare to papilo-tubular and solid-tubular which have more dense lymphocyte infiltration. (Table 3 ).

Table 1. Histopathological type of mastectomy specimens

\begin{tabular}{lrr}
\hline Histological type & \multicolumn{2}{c}{ Total cases } \\
\hline Ductal carcinoma in situ & 2 & $(2.8 \%)$ \\
Papilo-tubular carcinoma & 9 & $(12.8 \%)$ \\
Solid-tubular carcinoma & 16 & $(22.8 \%)$ \\
Scirrhous carcinoma & 31 & $(44.3 \%)$ \\
Mucinous carcinoma & 3 & $(4.3 \%)$ \\
Medullary carcinoma & 4 & $(5.7 \%)$ \\
Lobular carcinoma & 3 & $(4.3 \%)$ \\
Adenoid cystic carcinoma & 1 & $(1.4 \%)$ \\
Paget's disease & 1 & $(1.4 \%)$ \\
\hline Total & 70 & $(100.0 \%)$ \\
\hline
\end{tabular}

Table 2. The histopathologic profile of the mastectomy specimens

\begin{tabular}{lccc}
\hline Histopathologic profile & Positive & Negative & Total \\
\hline Lymphocytic infiltration & $\begin{array}{c}50(25 \mathrm{mild}, \\
19 \text { mod, } 6 \text { sev })\end{array}$ & 20 & 70 \\
Vascular invasion & 4 & 66 & 70 \\
Lymph vessel invasion & 16 & 54 & 70 \\
Fat invasion & 36 & 33 & 70 \\
Muscle invasion & 3 & 67 & 70 \\
Skin invasion & 1 & 69 & 70 \\
Lymph node involvement & 28 & 20 & $48^{*}$ \\
\hline
\end{tabular}

* No lymph node was found in 22 cases.

Table 3. Correlation between histological type and lymphocytic infiltration

\begin{tabular}{lccccc}
\hline $\begin{array}{l}\text { Histological } \\
\text { type }\end{array}$ & $\begin{array}{c}\text { No } \\
\text { filtration }\end{array}$ & Mild & Moderate & Severe & Total \\
\hline Ductal in situ & 1 & 1 & 0 & 0 & 2 \\
Papilo-tubular & 2 & 2 & 4 & 1 & 9 \\
Solid-tubular & 2 & 4 & 8 & 2 & 16 \\
Scirrhous & 13 & 12 & 5 & 1 & 31 \\
Mucinous & 1 & 2 & 0 & 0 & 3 \\
Medullary & 0 & 2 & 1 & 1 & 4 \\
Lobular & 0 & 2 & 1 & 0 & 3 \\
Adenoid cystic & 1 & 0 & 0 & 0 & 1 \\
Paget's disease & 0 & 0 & 0 & 1 & 1 \\
\hline Total & 20 & 25 & 19 & 6 & 70 \\
\hline
\end{tabular}


Table 4. Correlation between Histological type and various structure invasion

\begin{tabular}{lcccccc}
\hline Histological Type & Vasc & Lymph. & Fat & Muscle & Skin & Lymph node \\
\hline Ductal in situ & 0 & 0 & 0 & 0 & 0 & 0 \\
Papilo-tubular & $1 / 9(11 \%)$ & $4 / 9(44 \%)$ & $5 / 9(55 \%)$ & $1 / 9(11 \%)$ & $1 / 9(11 \%)$ & $3 / 9(30 \%)$ \\
Solid-tubular & $2 / 16(12 \%)$ & $3 / 16(18 \%)$ & $10 / 16(62 \%)$ & 0 & 0 & $8 / 16(50 \%)$ \\
Scirrhous & $1 / 31(3 \%)$ & $9 / 31(29 \%)$ & $18 / 31(58 \%)$ & $2 / 31(6 \%)$ & 0 & $14 / 31(45 \%)$ \\
Mucinous & 0 & 0 & $1 / 3(33 \%)$ & 0 & 0 & 0 \\
Medullary & 0 & 0 & 0 & 0 & 0 & $2 / 4(50 \%)$ \\
Lobular & 0 & 0 & $2 / 3(66 \%)$ & 0 & 0 & $1 / 3(33 \%)$ \\
Ad.cystic & 0 & 0 & 0 & 0 & 0 & 0 \\
Paget's & 0 & 0 & 0 & 0 & 0 & 0 \\
\hline Total & 4 & 16 & 36 & 3 & 1 & 28 \\
\hline
\end{tabular}

Table 5. Histopathologic profile of cases alive without disease

\begin{tabular}{|c|c|c|c|c|c|c|c|c|}
\hline Nr. & Age & Type & $\begin{array}{l}\text { Lymphocyte } \\
\text { infiltration }\end{array}$ & $\begin{array}{l}\text { Vasc. } \\
\text { Inv. }\end{array}$ & $\begin{array}{l}\text { Lymph } \\
\text { Inv. }\end{array}$ & $\begin{array}{l}\text { Fat } \\
\text { Inv. }\end{array}$ & $\begin{array}{l}\text { Muscle } \\
\text { Inv. }\end{array}$ & $\begin{array}{c}\text { Lymph } \\
\text { node }\end{array}$ \\
\hline 8902303 & 50 & Scirr & - & - & + & - & - & - \\
\hline 8900292 & 42 & Scirr & $\bmod$ & - & - & + & - & + \\
\hline 8910090 & 47 & Scirr & sev & - & + & + & - & + \\
\hline 8910224 & 62 & Scirr & mild & - & - & + & - & - \\
\hline 8911250 & 46 & Sol-tub & sev & - & - & - & - & - \\
\hline 9000785 & 50 & Sol-tub & mild & - & - & .. & - & - \\
\hline 9006042 & 40 & Scirr & $\bmod$ & - & $=$ & + & - & + \\
\hline 9109241 & 44 & Scirr & $\bmod$ & - & - & + & - & + \\
\hline 9104354 & 61 & Lob & $\bmod$ & - & - & - & - & - \\
\hline 9102082 & 41 & Lob & mild & - & - & + & - & - \\
\hline 9104800 & 61 & Sol-tub & $\bmod$ & - & + & + & - & + \\
\hline 9105836 & 34 & Pap-tub & mod & - & + & - & - & + \\
\hline 9107011 & 37 & Scirr & mild & - & - & - & - & - \\
\hline
\end{tabular}

Vascular invasion was found only in 4 out of 70 cases. The 4 cases were all of ductal invasive type, with the solid-tubular has the most frequent invasion. Lymphatic vessels invasion were present in 16 cases out of 70 cases, and more than half were of scirrhous type. Invasions of fat tissue were present in 36 out of 70 cases in which most of them were found in the scirrhous type. Muscle invasion and skin invasion were found only in 3 and 1 cases respectively. Two cases who has muscle invasion were of scirrhous type and 1 of papilo-tubular type; while the only 1 case with skin invasion was of papilo-tubular type (Table 4 ).

Nineteen cases showed involvement of 1-3 lymph nodes removed and 9 cases showed involvement of 5 to 21 nodes.

Five years follow up data with complete histopathological data which were available in 20 cases showed: 13 out of 20 were alive without disease, 6 cases were alive with disease and 1 patient died.

Among 13 cases that still alive without disease, 7 cases were of scirrhous type, 3 of solid-tubular type, 2 of lobular type and 1 of papilo-tubular type. Almost all cases showed lymphocytic infiltration, 4 cases with lymph vessel invasion, 7 showed fat invasion and 6 cases showed lymph node involvement (Table $5)$. 
Table 6. Histopathologic profile of cases alive with disease

\begin{tabular}{lcccccccc}
\hline Nr. & Age & Type & $\begin{array}{c}\text { Lymphocyte } \\
\text { infiltration }\end{array}$ & $\begin{array}{c}\text { Vasc. } \\
\text { Inv. }\end{array}$ & $\begin{array}{c}\text { Lymph } \\
\text { Inv. }\end{array}$ & $\begin{array}{c}\text { Fat } \\
\text { Inv. }\end{array}$ & $\begin{array}{c}\text { Muscle } \\
\text { Inv. }\end{array}$ & $\begin{array}{c}\text { Lymph } \\
\text { node }\end{array}$ \\
\hline 9008071 & 37 & Scirr & mild & - & - & - & + \\
9109331 & 42 & Scirr & & - & - & - & - \\
9105609 & 30 & Scirr & mod & - & - & + & - \\
9107232 & 53 & Scirr & mild & - & - & + & + \\
9107430 & 39 & Pap-tub & mild & - & - & - & - \\
9111031 & 33 & Sol-tub & - & - & - & - & - \\
\hline
\end{tabular}

Six cases alive with disease had scirrhous type in 4 cases, 1 has papilo-tubular and 1 has solid-tubular type. Their age was relatively younger than the group who lived without disease (mean age 39 vs. 47.3 years). Almost all of them showed lymphocyte infiltration, 2 had fat invasion, 1 had muscle invasion and 3 had lymph node involvement. The only 1 case who died was of 33 years old with scirrhous type, and had lymph vessel and fat tissue invasion.

\section{DISCUSSION}

The most frequent histological type found is ductal type, comprising more than half of the total cases. Most of the tumors had lymphocyte infiltration. The prognosis significance of lymphocyte was a subject of controversy. Some investigators found it related to the favorable prognosis, ${ }^{4}$ while other group did not 5 . Looking at our series, the scirrhous type was the less infiltrated by lymphocyte, and this type has the worse prognosis compare to the ductal invasive subtypes like papilo-tubular and solid-tubular. The discordant results might need to be clarified by further identification of the Iymphocyte sub-population. If the lymphocyte population is B cell, they have no meaning in the tumor surveillance, while if the population is $T$ lymphocyte it has the property of tumor control. The presence of $B$ lymphocyte could be result of secondary infection. In breast cancer, the presence of infection is possible if ulceration occur; which are commonly complicating the advance inoperable cases. In operable cases, which is of earlier stage it is uncommon to find this complication. So, the T lymphocyte is most likely to be the main population in this condition, and consequently it can be expected as an indicator of better outcome.

We found lymphatic invasion more common than vascular invasion. These results were similar to Fisher's finding. ${ }^{6}$ Structurally, vascular vessels are more resistant to invasion due to its thicker layer than the lymphatic vessels, which are composed only by a single layer of endothelial cell. Lymphatic emboli have an unfavorable prognosis in node negative patients treated by mastectomy ${ }^{7}$ and give rise to a higher local recurrence rate in node negative patients who underwent breast conserving treatment. ${ }^{8}$

Blood vessel invasion is also still a subject of controversy, but it was recorded that visceral metastasis occurred in $67 \%$ of cases with blood vessel invasion, compared to only $35 \%$ visceral metastasis in the absence of blood vessel invasion in stage I cases. ${ }^{9}$ Death, due to metastasis breast cancer was significantly greater in frequency in women with blood vessel invasion irrespective of their total lymph node involvement in stage II cases. ${ }^{10}$

Weigand et alll in their study revealed a strong correlation between blood vessel invasion and early recurrence. The presence of blood vessel invasion in their series was much higher than our study and Fisher's large series. ${ }^{6}$ Several investigators claimed the high interobserver variation in assessing vessels invasion, either lymph or blood. The most possible source of this variation is the difficulty in differentiating between vessels and tissue artifact affecting carcinomatus duct. The use of special staining is then highly recommended to overcome this problem, either histochemically using elastic staining or immunohistochemically using endothelial antibodies. ${ }^{12-13}$ Fat tissue invasion has never been regarded as a prognostic factor. Our series revealed more than half cases with fat invasion, and the significance of which couldn't be stated yet. Recently, several studies has done to correlate the presence of proteolytic enzymes, like collagenase and cathepsins bear by the tumor cells, with their ability to degrade the basement membrane and extracellular matrix as their initial steps to metastasis. ${ }^{14-16}$ It is reasonable then to speculate that the tumor cells might have an ability to 
produce a lipolytic enzyme besides proteolytic enzymes; and if it is proced to be the case, it might serve as an additional bad prognostic factor.

Cases who are alive without disease are of older age compare to cases that are alive with disease. The most prevalence type in all groups (alive with/without disease and died) were ductal type, mostly of scirrhous subtype. Among the group alive with disease, lymphocytic infiltration was mostly mild, while in the group without disease, the infiltration were mostly moderate to severe. The occurrence of lymph node metastasis was found comparably in the group with disease and the group without disease. A higher yield of lymph node positivity can be obtained actually by performing special staining using antibodies against epithelial cells. This procedure had been done by some investigators. 17-19 They had proved around $30 \%$ positive finding in negatively stated lymph nodes by routine $\mathrm{H} \& \mathrm{E}$ staining. This staining is able to find the micromestastases, which is usually overlooked by routine staining. By performing this staining, it will probably change the clinical or pathological staging in certain cases and consequently the management and prognosis prediction.

It seems that breast cancer affecting younger age group is more aggressive. The mean age of cases were decreasing from group of cases alive without disease, alive with disease and deceased case. If we assume that menopausal status is related to age, then this finding was differed from American breast cancer cases, in which, post menopausal group which were generally of older age, showed poorer survival compare to the premenopausal group. ${ }^{20}$ However, several studies showed that higher hormon receptor positivity, another indicator of better clinical outcome, were found in post menopausal women $12-21$ and these are in keeping with our findings. This finding may indicate the difference of cancer biology between Asian and non-Asian, which might be due to genetic and geographic properties.

Lymphocyte infiltration seems also play a role for a better outcome among invasive ductal carcinoma. The presence and severity of lymphocyte infiltration was decreasing from the group alive without disease, alive with disease and the died case. Of interest to note is the finding that none of the cases in the group alive with disease showed lymph and blood vessels invasion, unlike the other two groups, especially the group alive without disease. The explanation of this phenomenon might be the multisteps process of me- tastasis. After being able to invade the vessels, the tumor cells must be able to survive the defense mechanism encountered in the circulation, and also is the new environment of tissue or organ where they are entrapped. Then, the cell must be able also to proliferate and grow in distant organ. 22

It will be very interesting to design a further study on a larger series of cases with the help of an additional ancillary techniques in order to get a more accurate information about the nature of lymphocyte infiltrates, blood and lymph vessels invasion and the presence of an occult or micrometastasis.

\section{REFERENCES}

1. Cornain S, Mangunkusumo R, Nasar IM, Prihartono J. Ten most frequent cancers in Indonesia: Pathology based cancer registry data of 1988-1992. In: Cancer registry in Indonesia, National Cancer Registry Center, Jakarta Coordinating Board, 1997.

2. Tjindarbumi D, Ramli M, Watanabe S, Darwis I, Sakamoto G, Cornain S, Tjahjadi G, Soetrisno E, Ohno Y, Roostini ES, Prihartono J, Suzuki S, Budiningsih S, Wakai K. Clinicopathological aspects of breast cancer: A joint study between Indonesia and Japan. Med J Indones 1995; 4: 148-53.

3. Japanese Breast Cancer Society. The general rules for clinical and pathological recording of breast cancer. Jpn J Surg 1989; 19: 612-32

4. Stenkust B, Bengtsson E, Dahlquist B, Eklund G, Erikson O, Jakrans T, Nordin B. Predicting breast cancer recurrence. Cancer 1982; 50: 2884-93.

5. Dawson PJ, Ferguson DJ, Karrison T. The pathological linding of breast cancer in patient surviving 25 years after radical mastectomy. Cancer 1982; 50: 2131-8.

6. Fisher ER, Gregorio RM, Fisher B. The pathology of invasive breast cancer: A syllabus derived from finding of the $\mathrm{Na}$ tional Surgical Adjuvant Breast Cancer Project, 1975; 36: 2 85.

7. Nime F, Rosen PP, Thaler H, Ashikari R, Urban JA. Prognostic significance of tumor emboli in intramammary lymphatics in patients with mammary carcinoma. Am J Surg Pathol 1977; 1:25-30. In : Rosen PP. Invasive duct carcinoma and morphological prognostic markers. Breast pathology. Chapt. 15 Lippincot-Raven. Philadelphia-New York 1996.

8. Clemente CG. Boracchi P, Andreola S. Del Vecchio M, Veronesi P, Rilke FO. Peritumoral lymphatic invasion in patients with node negative mammary duct carcinoma. Cancer 1992; 69:1396-403

9. Rosen PP, Saigo PE, Braun DW Jr, Weathers E, de Palo A. Prediclors of recurrence in stage I (T1NOMO) breast carcinoma. Ann Surg 1981; 193: 15-25. In : Rosen PP. Invasive duct carcinoma and morphological prognostic markers. Breast pathology. chapt 15 Lippincot-Raven PhiladelphiaNew York 1996. 
10. Rosen PP, Saigo PE, Braun DW Jr, Weathers E, Kinne DW. Prognosis in stage II (T1N1M0) breast cancer. Ann Surg 1981; 194: 576-84. In: Rosen PP. Invasive duct carcinoma and morphological prognostic markers. Breast pathology. Chapt. 15 Lippincot-Raven. Philadelphia-New York 1996.

11. Weigand AR, Isenberg WM, Russo J, Brennan J, Rich MA and the Breast Cancer Prognostic Study Associates. Blood vessels invasion and axillary lymph node involvement as a prognostic indicators for human breast cancer. Cancer, 1982; 50: 962-9.

12. Oosterhuis JW. Breast Cancer: Pathological Aspects. In; Cornain S, editor. Advanced Postgraduate Course on Oncology, Jakarta, November 1993.

13. Leong ASY, Raymond WA. Prognostic Parameters in Breast Cancer. Pathology, 1989; 21: 169-75.

14. Murakami Y. Decision for prophilactic neck dissection based on immunohistological evaluation of biopsy specimen. In : Smee R, Bridger PG eds. Proceedings of the $2^{\text {nd }}$ World congress on laryngeal cancer. El sevier, Amsterdam, Lausanne, New York, Oxford, Tokyo 1994; 582-8.

15. Leonoe D, Nesland JM, Holm R, Sobrinko-Simoes M. Expression of laminin, collagen IV, Fibronectin and type IV collagenase in gastric carcinoma. Cancer 1994;73:518-27.

16. Aznavoorian S, Murphy AN, Settler-Srevenson WG, Liotta
LA. Molecular aspects of tumor cell invasion and metastasis. Cancer 1993; 71(4): 368-83.

17. Mc Guckin MA, Cummings MC, Walsh MD, Hohn BG, Bennet IC and Wright RG. Occult axillary node metastasis in breast cancer : their detection and prognostic significance. British J Cancer 1996; 73: 88-95.

18. Sedmak DD, Meineke TA, Knechtges DS, Anderson J. Prognostic signiticance of cytokeratin-positive breast cancer metastasis. Modern Pathology 1989; 2: 516-20.

19. Raymond WA, Leong ASY. Immunoperoxidase staining in the detection of lymph node metastasis in stage I breast cancer. Pathology 1989; 21: 11-5.

20. Sakamoto G, Sugano H, Hartman WH. Comparative Pathological Study of Breast Carcinoma among American and Japanese Women. In: McGuire WL, ed. Breast Cancer. Nashville USA: Plenum Publishing Corporation, 1981; 211-31.

21. LesserML, Ropsen PP, Senie RT, Duthie K, Menendez-Botet C, Schwartz MK. Estrogen and progesteron receptors in breast carcinoma. Correlations with epidemiology and pathology. Cancer 1981; 48: 299-309.

22. Tarin D. Metastasis; Secondary proliferation in distant organs. In: Pusztai L, Lewis CE, Yap E eds. Cell Proliferation in cancer. Oxford University Press, Oxford 1996: 317-41. 